EDUCATION

Research, hnovorition and Solutions on-line ${ }^{\oplus}$
PSYCHOLOGY

I+D+i
Electronic Journal of Research

in Educational Psychology

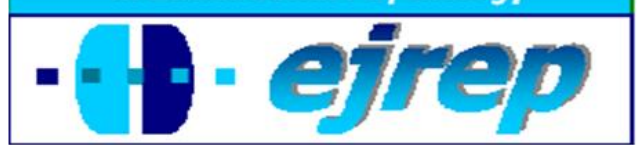

\title{
Grammar Instruction and Error Correction: A Matter of Iranian Students' Beliefs
}

\author{
Mahyar Ganjabi \\ Department of Foreign Language Teaching \\ Payemenoor University, Tehran

\section{Iran}

Correspondence: Mahyar Ganjabi, Department of Foreign Language Teaching, Payamenoor University, Tehran, Iran. E-mail: mahyarganjaby@gmail.com

(C) Education \& Psychology I+D+i and Editorial EOS (Spain) 


\begin{abstract}
Introduction. So far the role of grammar instruction and error correction has been mainly analyzed from the teachers' perspectives. However, learners' attitudes can also affect the effectiveness of any type of learning, especially language learning. Therefore, language learners' attitudes and beliefs should also be considered as a determining factor in the success of language teaching process. This study intended to explore the language learners' attitudes towards grammar instruction and error correction and see how they perceive them.
\end{abstract}

Method. The participants of this study were 214 high school female students, studying at the third grade and aged around 17 years old. They were asked to respond to questionnaire investigating the students' beliefs about grammar instruction and error correction.

Results. Based on the factor analysis and qualitative analysis procedures, it was concluded that Iranian high school students had varied attitudes towards the role of grammar and the manner of teaching grammar. Their ideas regarding the role of grammar ranged from its use in communication to the mere use of grammar in learning English for academic purposes. Also, the activities preferred by the students included a range of both mechanical and meaningful drills.

Conclusion. It was concluded that to maintain the students' interest and motivation, L2 teachers and practitioners must vary the type of activities and procedures to teach grammatical points. Teachers should come to this understanding that students' beliefs and attitudes have a determining effect on the success or failure of their teaching enterprise.

Keywords: second language learning, grammar instruction, error correction, students' beliefs 


\section{Instrucción sobre gramática y corrección de errores: cuestión de creencias de los alumnos iraníes}

\section{Resumen}

Introducción. Hasta el momento, el papel de la enseñanza de la gramática y corrección de errores ha sido analizada principalmente desde la perspectiva de los profesores. Sin embargo, las actitudes de los alumnos también pueden afectar la efectividad de cualquier tipo de aprendizaje, especialmented el lenguaje. Por lo tanto, las actitudes de los estudiantes hacia el idioma y las creencias también deben ser considerada como un factor determinante en el éxito del proceso de enseñanza de idiomas. Este estudio pretende explorar las actitudes de los estudiantes de idiomas "para la gramática en la construcción y corrección de errores y ver cómo los perciben.

Método. Los participantes de este estudio fueron 214 estudiantes de la escuela femenina que estudiaban en el tercer grado y de 17 años de edad. Se les pidió que respondieran al cuestionario de investigación sobre las creencias de los estudiantes sobre la enseñanza de la gramática y corrección de errores.

Resultados. Basado en el análisis de factores y procedimientos de análisis cualitativo, se concluyó que los estudiantes de secundaria habían variado sus actitudes hacia el papel de la gramática y la forma de enseñanza de la gramática. Sus ideas sobre el papel de la gramática van desde su uso en la comunicación hasta el mero uso de la gramática y del aprendizaje de Inglés para fines académicos. Además, las actividades preferidas por los estudiantes incluyen toda una gama de ejercicios mecánicos y significativos.

Conclusión. Se concluyó que, para mantener el interés de los estudiantes y la motivación, los profesores L2 y los profesionales deben variar el tipo de actividades y procedimientos para enseñar a los puntos gramaticales. Los profesores deben llegar al entendimiento de que las creencias de los estudiantes y las actitudes tienen un efecto determinante en el éxito o el fracaso de su empresa de enseñanza.

Palabras Clave: aprendizaje de segundas lenguas, enseñanza de la gramática, la corrección de errores, las creencias de los estudiantes 


\section{Introduction}

A review of language teaching history shows that formal instruction has received much attention and many research studies have been done on how to teach grammar effectively. "Yet not only has this area of research been largely inconclusive in identifying optimal strategies for grammar learning, but also it has actually provided very little insight into the actual processes of L2 grammar teaching as these are perceived by teachers" (Borg, 1999, p. 20-21). Also, from the early days of SLA life as an interdisciplinary field, grammar has received much attention from different prominent researchers and scholars. For instance, Chomsky in formulating his generative grammar posits that knowing a language involves knowing grammar - "a domain-specific form of knowledge representation that allows the language user to create a nearly infinite set of well-formed utterances and that grammar is a characterization of the knowledge of an idealized speaker-hearer" (Chomsky, as cited in Seidenberg \& MacDonald, 1999, p. 3-4).

According to Rutherford (1988), over the relatively long history of language teaching "the teaching of grammar had often been synonymous with foreign language teaching" (Celce-Murcia, 1991, p. 459). The foreign language teachers and researchers based on what role they attributed to grammar have been classifed into three groups. First are those who believe that grammar instruction and error correction as a type of negative evidence are necessary for post-puberty classroom language learning (Higgs \& Clifford, 1982; Valette, 1991). Second are those who believe that grammar instruction and corrective feedback can have a positive effect on interlanguage development (Lalande, 1982; Lightbown, 1998; Long \& Robinson, 1998; Lyster, Lightbown \& Spade, 1998). Finally, there are those who have no belief in grammar instruction and error correction and believe that classroom time as the only place where talk for learning or 'learning talk' (Van Lier 2001) happens should not be devoted to such matters (Krashen, 1985, 1999; Semke, 1984; Terrel, 1977; Truscott, 1999). As Schulz (2001) considers, the third group believes in Full Access to UG and the idea that the postpuberty second language learning utilizes the same processes available in the pre-puberty primary language acquisition and the available classroom time should be exploited in the best possible way to provide learners with some opportunities to communicate meaningfully and to receive comprehensible input. In other words, as noted by Ellis (1995), this position is motivated by research showing that learners progress along a natural acquisitional sequence for grammatical structures which is resistant to interference from direct instruction. 
Recent publications emphasize rethinking the strong anti-grammar position advocated by some proponents of CLT approaches. Indeed as Richards (as cited in Celce-Murcia, 1991) points out, there is still no actual reliable evidence that proves communicative language classrooms in which teachers are advised to preclude any learner focus on form produce better learning outcomes than do more traditional classrooms that are mainly acharactrized by focus on form. Also, Widdowson (1990) characterized grammar as a 'liberating force' that is, grammar is a resource which can play a liberating role to free language learner from an overdependency on lexicon and context for what they intend to express. In the same vein, Cullen (2008) identified three key design features of the tasks that consider grammar as a liberating force: "learner choice over which grammatical structures to use; a process of 'grammaticization' where the learners apply grammar to lexis; and opportunities to make comparisons and notice gaps in their use of grammar" (p. 221).

History of language teaching has witnessed several attempts to integrate grammar into the language instruction courses. Schachter (1991) conjectured that the efficacy of grammar instruction and corrective feedback may well depend on such factors as aspect of language being taught, learner characteristics such as instance, age, aptitude, motivation, and learning style, and instructional context. Lyster, Lightbown, and Spada (1999), reviewing several studies, came to the conclusion that "corrective feedback is pragmatically feasible, potentially effective, and, in some cases, necessary" (p. 457). Fotos (1994) employed grammar consciousness-raising tasks to investigate the possibility of integrating grammar instruction and communicative language use and came to this conlusion that the tasks successfully promoted both proficiency gains and L2 negotiated interaction in the participants. Thus, grammar consciousness-raising tasks can be recommended as one way to integrate formal instruction within a communicative framework. In the same vein, Ellis (1995) used interpretation tasks for grammar teaching. This approach emphasized helping learners to notice grammatical features in the input, comprehend their meanings, and compare the forms present in the input with those occurring in learner output and finally leading to interlanguage development. Thus, although we expect to find a solution for this dilemma of when and how to teach grammar, it should be kept in mind that grammar instruction is an integral part of language teaching and learning and no one can dismiss grammar instruction altogether because so far there is no convincing evidence emphasizing that doing so would ultimately be beneficial to second or foreign language learners (Celce-Murcia, 1991). 
So far, the role of grammar instruction and error correction has been mainly analyzed from the teachers' perspectives. But as Larsen-Freeman and Long (1991) point out, learners' attitudes can affect the effectiveness of any type of learning, especially language learning. Therefore, language learners' attitudes and beliefs should also be considered as a determining factor in the success of language teaching process. This study intended to explore the language learners' attitudes towards grammar instruction and error correction and see how they perceive them.

\section{Review of the literature}

Over the past two decades, all the major language teaching methods have devoted differing importance to grammar and vary on whether explicit grammar instruction is necessary to be included in the second or foreign language classroom (Celce-Murcia, 1991). To put it another way, according to Loewen et al. (2009), the history of language teaching can be reviewed in terms of form-focused versus meaning-focused instruction. Meaning-focused instruction places emphasis on the primacy of meaning and content and assumes that the process of L2 teaching should exemplify that of first language acquisition (Long 2001). According to the proponents of primacy of meaning tradition, language is best acquired when it is approached implicitly and unconsciously. Any overt attention to language forms is seen as unnecessary and unfruitful (Krashen, 1985, 1999; Long, 2001). Immersion Programs can be considered as a good example of this tradition. These programs mainly revolved around the notion that the only responsibility of language teachers is to provide learners with ample content-based input (Skehan, 2001). Although this tradition has been adopted by many language teachers and practitioners all over the world, many studies have shown some counterevidences to its effectiveness. According to Swain (as cited in Skehan, 2001), the mere provision of comprehensible input cannot affect the interlanguage of learners. She believes that comprehension is mainly based on the use of schematic and contextual knowledge, and then it can be regarded as a linguistic skill whose development will not have any effects on linguistic system (as cited in Skehan, 2001). To draw meaning, the listener does not need to rely on the systematic knowledge and due to the fact that systematic system is still underdeveloped, the L2 learner mainly uses the schematic and contextual systems developed during the L1 acquisition to understand the second language input (Gass \& Selinker, 2008). 
On the other hand, form-focused instruction has been employed favourably by many language practioners. The aim of early focus-on-form research studies was primarily concerned with finding out whether this type of instruction enabled learners to effectively acquire the structures they had been taught (Ellis 1984). These early studies did not distinguish different kinds of form-focused instruction. Instead, they tended to treat focus on form as a generic phenomenon to be contrasted with focus on meaning. According to Long (2001), the language teaching approaches can be classified according to whether they focus on form or forms. Long (2001) points out that focus on forms can affect language acquisition in three different ways: rate of acquisition, process of language acquisition and ultimate level of achievement. The main argument in support of form-focused instruction comes from the Schmidt's Noticing Hypothesis which states that attention is essential to learning; that is, that there is no learning without attention (Schmidt, as cited in Gass \& Selinker, 2008). Although the strong version of this Hypothesis has been refuted, it is widely accepted that selective attention plays a major role in learning.

Long (2001) makes a distinction between form-focused and forms-focused instruction. Although the focus-on-forms explicitly draws learners attention to language forms, the focus-on-form approach "overtly draws learners attention to linguistic elements as they arise incidentally in lessons whose overriding focus is on meaning or communication" (Long, 2001, p. 184). This is similar to what Sharwood-Smith (as cited in Gass \& Selinker, 2008) refers to as enhanced input which is characterized by the input which is enhanced either by an external source (e.g. teacher) or an internal source (learners relying on their own resources). Although there is still considerable controversy around the effectiveness of each of these two approaches, many studies have shown the effectiveness of the form-focused approach (Lightbown \& Spada, 1990; Loewen, 2005; Long, 1983).

Different scholars have also developed different frameworks and approaches that believed to be the best for classroom grammar instruction. For example, Celce-Murcia (1985) developed a framework about how grammar should be taught in language classes. Her framework involves two types of variables: learner variables (i.e. learning style, learner proficiency and the educational background of the learners) and instructional variables (i.e. educational objectives, medium and register, and finally learners' immediate goals). Celce-Murcia (1991) also proposed that three conceptions of teaching grammar are commonly found in literature: teaching grammar as meaning (e.g. teaching grammar in context using some fully 
illustrated and well-demonstrated examples); teaching grammar as social function (e.g. grammar used in the service of socially appropriate messages), and teaching grammar as discourse (e.g. learning the link between grammar and discourse). In another framework, Bachman and Palmer (1996) made a distinction between two types of grammar activities: those that treat grammar as an object to be studied and analyzed and those that treat grammar as a communicative tool. Also, Batstone and Ellis (2009) developed a framework consisting of three principles for more effective grammar teaching: the given-to-new principle (i.e. learning a new grammatical item through the exploitation of what the learners already know about the world), the awareness principle (i.e. making learners aware of how a particular meaning is encoded by a particular grammatical form), and the real-operating conditions principle (i.e. treating grammar a communicative tool).

To summarize, the grammar teaching research, as noted by Borg (1999), can be illustrated by three points: inconclusive in the sense that a consensus regarding the best way to teach grammar has not been reached; experimental in the sense that researchers have set up instructional contexts in which the effects on student achievement of different strategies can be compared; and none of them have considered the role of teacher cognitions underlying practices.

Furthermore, until recently the role of grammar instruction and error correction has been mainly investigated from the teachers' perspectives (Basturkmen, Loewn \& Ellis, 2004; Borg, 1999; Ellis, 2006; McCargar, 1993; Peacock, 2001; Phipps \& Borg, 2009). According to Burgess and Etherington (2002), the factor that teachers take into consideration when deciding what aspects of grammar to present is students' expectation and past experience of grammar learning. Also, educational research has shown that to have a better picture of classroom instruction, one should study the teacher cognition, that is, "the store of beliefs, knowledge, assumptions, theories, and attitudes about all aspects of their work which teachers hold and which have a powerful impact on teachers' classroom practices" (Borg, 1999, p. 19).

In addition to teachers' beliefs about grammar teaching, the learners' beliefs as the key determinant of the language teaching success should also be taken into account. Some scholars have noted the difficulty of differentiating the terms learners' beleifs and metacognitive knowledge (Flavel, 1979; Wenden 1999). Flavell (1979) defines metacognitive knowledge as "what learners know about learning, and to the extent a learner has made distinctions, lan- 
guage learning" (Ganjabi, 2011, p. 46). According to Wenden (1999), learner beliefs and metacognitive knowledge have both similar and different meanings. On the one hand, they are similar in that they can be described in terms of the features that identify metacognitive knowledge. On the other hand, they are in that they are value-related and more persistent to change. These learners' beliefs are usually encountered by the teachers in the classroom. For example, learners' beliefs regarding learners' and teacher's roles can lead them to resist an especific teaching technique (Ganjabi, 2011).

Brown's (as cited in Larsen-Freeman \& Long, 1991) research suggests that learners' attitudes towards the learning situation affect their degree of success. In a review of diary studies, Schumann (as cited in Larsen-Freeman \& Long, 1991) came to this conclusion that any difference between teacher's and learner's agendas can have negative effect on the learners' attitudes towards the learning situation. Also, it has been reported that learners' beliefs and attitudes can influence the strategy that they use while learning a new language (LarsenFreeman \& Long, 1991). For example, investigating the relationship between college EFL (English as a foreign language) students' beliefs about language learning and their use of learning strategies, Yang (1999) found that language learners' self-efficacy beliefs about learning English were strongly related to their use of all types of learning strategies, especially functional practice strategies.

As it is clear from these studies, learners should be regarded as one of the most influential determiners of language instruction sucsess. The investigation of learners' beliefs was initiated by the Elaine Horwitz's (1988) ten year research on the beliefs about language learning. Prior to her research model, no systematic studies had been done to analyse the students' beliefs about foreign language learning (Ganjabi, 2011). To do so, he developed a 34-item questionnaire called Beliefs About Language Learning Inventory (BALLI) to measure five categories (nature of language learning, difficulty of language learning, foreign language aptitude, learning and communication strategies, and motivation and expectations) (Ganjabi, 2011). "Although the questionnaire primarily was designed to measure learners' general beliefs, several of its items are related to the learners' attitudes towards grammar instruction. The results showed that learners generally had favourable attitudes towards grammar instruction and viewed it as an integral part of language learning" (Horwitz as cited in Ganjabi, 2011, p. 47). 
One of the recent and probably the most influential studies examining L2 learners' beliefs about grammar instruction was conducted by Schulz (1996, 2001). In his 1996 study, Schulz examined the beliefs of US postsecondary foreign language students and teachers about grammar instruction and error correction. The results showed that the majority of the students thought it vital to be corrected while speaking in class, whereas few teachers thought this to be so. Despite this discrepancy, the majority of teachers and students reported that the errors should be explicitly corrected. In 2001, he replicated the 1996 study with a large group of Colombian and US foreign language learners. Data comparisons indicated relatively high agreement between students as a group and teachers as a group across cultures on the majority of questions. The teachers and learners also reported that the grammar instruction is not sufficient but should be complemented with authentic communication.

In another study, Sakui and Gaies (1999) investigated the beliefs about language learning of almost 1300 Japanese university learners of English. One of the aims of this study was to describe the beliefs about language learning of Japanese learners of English and to determine, through factor analysis, how those beliefs are organized. They found that teacher beliefs and attitudes had direct impact upon learners' beliefs. According to their study, many of the respondents' beliefs about learning English correspond to the distinction which many teachers would make between traditional and contemporary approaches to language teaching and learning.

Hawkey (2006) conducted a study in Italy employing a combination of qualitative and quantitative data collection methods. The study findings suggested interesting differences between the perceptions of learners and teachers on some of the activities in their foreign language classes. While both sides agreed in general on the virtues of communicative approaches to language teaching, there were interesting differences in the perceptions of learners and teachers on the prominence of grammar and pair works in their classes. He concluded that these differences might indicate potential problem areas of lesson planning and implementation which could usefully be given attention on teacher support programs.

Loewen et al. (2009) investigated the beliefs of L2 learners regarding the controversial role of grammar instruction and error correction. A total of 754 L2 students at an American university completed a questionnaire consisting of 37 Likert-scale items and 4 open-ended prompts. The quantitative items were submitted to a factor analysis, which identified 6 under- 
lying factors (efficacy of grammar, negative attitude toward error correction, priority of communication, importance of grammar, importance of grammatical accuracy, and negative attitude toward grammar instruction). These factors were then used to investigate differences in beliefs among learners studying different target languages. In addition, themes emerging from the qualitative data were identified. The results indicated that among learners studying English as a second language and those studying a foreign language, there were varied beliefs about grammar instruction and error correction.

\section{The Present Study}

Considering the significant effects that students' beliefs and attitudes can have on the outcome of language teaching instruction and the scarcity of studies investigating grammar teaching and error correction from the perspective of language learners (Batstone \& Ellis, 2009; Loewen et al, 2009; Phipps \& Borg, 2009), this study sought to bridge this gap by posing the following questions:

1. What underlying constructs are present in L2 learners' responses to a questionnaire regarding their beliefs about grammar instruction and error correction?

2. What statements do L2 learners provide about grammar instructions based on four open-ended statements?

\section{Method}

\section{Participants}

The participants of this study were 214 high school female students, studying at the second and third grade and aged around 17 years old. They were studying at Refah high school which is located in Tehran and is considered as a private school with high ranking among the other high schools. The particiapnts were from six classes (three second grade classes and three third grade classes). The rationale for conducting this research study at the high school setting was that the Iranian high school students are still confronted with teacherfronted classrooms whose primary focus is on teaching grammar. Therefore, surveying the attitudes of high school students was supposed to provide the researcher with a representative sample of Iranian English language students' perspectives. 


\section{Measures}

After reviewing the literature on the grammar instruction and error correction, the questionnaire used by Loewen et al. (2009) was found suitable for the purpose of this study. However, the original questionnaire consisting of three parts was reduced to two parts to make it more suitable for the exiting participants: a) a Likert-scale response (quantitative) section, and b) an open-ended question (qualitative) section. The quantitative section contained 24 items surveying learners' beliefs, 13 of which were adopted from Schulz (1996, 2001) and the remaining were created jointly by the Loewen and his team through intensive group discussion and extensive onsite piloting with L2 learners and instructors. The items in the quantitative section covered a range of aspects of grammar instruction and error correction, including questions about grammar instruction as well as various aspects in relation to the four skills. The number of items in the original questionnaire was 37 (24 grammar-related items and 13 distracters). Following profound analysis of the context of the present study (i.e. the learners' and teachers' classroom limitations), it was decided to omit the distracters while keeping the grammar-related items (See Appendix A).

A qualitative section was also included in the questionnaire in order to deeply analyze the learners' attitudes and beliefs regarding grammar instruction and error correction. According to Genesee and Upshur (1996), the multiple-choice answer formats can be used only when most or all of the responses are known in advance and grouped into non-overlapping categories. In contrast, "the open-ended repose format can be used when one does not know what the response possibilities are or when they cannot be presented in discrete categories" (Genesee \& Upshur, 1996, p. 132).

\section{Procedure}

As mentioned above, the data was collected from a group of high school students in Tehran. Based on the qualitative nature of the study, the researcher made no intervention in the routine order of the classroom such as intervention, randomization and data manipulation. That is, an ex post facto design was chosen for the purpose of this study. The questionnaire was distributed among the respondents and they were required to answer the closed-ended and open-ended sections based on their past experiences of participating in the language classes. The students were also told that they could ask any questions about whatever they felt 
ambiguous. In order to minimize the ambiguity inherent in language-related questionnaires, the existing questionnaire was translated into the students' mother tongue (e.g. Persian). The rationale was to guarantee the students' understanding of questionnaire items. The translated version was given to two highly proficient English-Persian bilinguals to review and to give comments on the felicity, intelligibility, and faithfulness of the translated items. Based on their comments, some minor changes were implemented and the translated instrument was finalized for distribution among the intended participants of the study. Translating the original questionnaire was supposed to be more helpful in the open-ended section because the students could answer more precisely and the amount of their contribution was supposed to increase.

\section{Dates analysis}

The collected data was analysed at two phases: quantitative and qualitative. At the quantitative phase, they data drawn from the Likert scale type of questions were put into analysis. At the the qualitative phase, the responses the students the open-ended questions were thematically analyzed.

\section{Quantitative Analysis}

Due to no agreed upon proposal regarding the number of factors underlying learners' beliefs to date, the learners' responses to Likert scale items underwent principle component factor analysis (PCA) using SPSS version 17 . Factor loadings of .30 and greater on the obliquely rotated factor matrix were considered significant. Also, the reliability of the questionnaire was determined to be significant $(\mathrm{r}=.80)$.

\section{Qualitative Analysis}

The respondents' responses to the four open-ended questions were subjected to the content analysis procedure. The content analysis consisted of two phases. First, the researcher transferred the learners' responses to an electronic file. In the coding phase, an attempt was made to group the similar responses and identify the common themes underlying them. To ensure the inter-rater reliability of the identified themes, another researcher was invited to check them. The outcome showed that there was high degree of consensus between the two researchers regarding the identified themes. 


\section{Results and discussion}

\section{Quantitative Results}

Prior to performing principle component factor analysis (PCA), the suitability of data for factor analysis was assessed. Inspection of the correlation matrix revealed the presence of many coefficients of 3 and above. The KMO value was .62, exceeding the recommended value of .6 (Kaiser, as cited in Pallant, 2007) and Bartlett's Test of Sphericity reached the statistical significance (the Sig. value should be .05 or smaller) supporting the factorability of the correlation matrix.

PCA revealed the presence of five factors with eigenvalues exceeding 1, explaining $23.86 \%, 16.68 \%, 9.39 \%, 8.31 \%$, and $7.45 \%$ of the variance respectively. These nine components explain a total of 65.69 per cent of the variance. An inspection of the screeplot revealed a clear break after the third component. Using Catell's (as cited in Pallant, 2007) scree test, it was decided to retain three components for further investigation (See Figure 1). This was further supported by the results of Parallel Analysis, which showed only two components with eigenvalues exceeding the corresponding criterion values for a randomly generated data matrix of the same size ( 24 variables $\times 214$ participants).

Figure 1. The screeplot for the variables

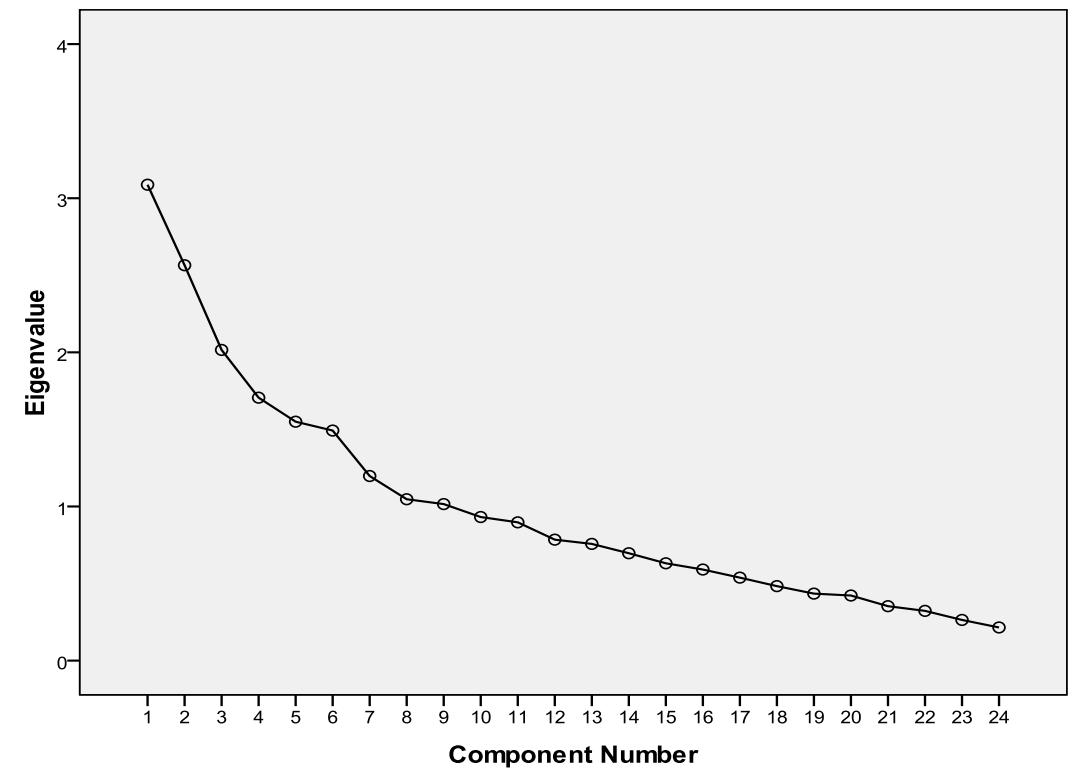


The two-component solution explained a total of $40.54 \%$ of the variance, with Component 1 contributing $23.86 \%$ and Component 2 contributing $16.68 \%$. Table 1 displays the factor loadings for the three factors. The first factor, labeled 'efficacy of grammar' based the categorization of Loewen et al (2009) contains those items that address the usefulness of learning grammar both for learning and using a second language. The second factor, e.g. 'negative attitude to grammar instruction and error correction' as it is clear from its name involves all those items that focus on the grammar instruction and error correction. The last factor identified is called priority of communication.

Table 1: Rotated Factor Loadings for Learner Beliefs

\begin{tabular}{|c|c|c|c|}
\hline \multirow[t]{2}{*}{ Items } & \multicolumn{3}{|c|}{ Component } \\
\hline & 1 & 2 & 3 \\
\hline \multicolumn{4}{|l|}{ - Importance of Grammar } \\
\hline $\begin{array}{l}\text { 1.Studying a grammar formally is essential for mastering a second lan- } \\
\text { guage }\end{array}$ & .38 & & \\
\hline $\begin{array}{l}\text { 2. I usually keep grammar rules in mind when I write in a second lan- } \\
\text { guage. }\end{array}$ & .58 & & \\
\hline 3. Knowing a lot about grammar helps my reading. & .41 & .34 & \\
\hline $\begin{array}{l}\text { 5. My second language improves most quickly if I study the grammar } \\
\text { of the language. }\end{array}$ & .50 & .39 & \\
\hline 8. I like studying grammar. & .67 & & \\
\hline $\begin{array}{l}\text { 9. People will respect me if I use correct when speaking a second lan- } \\
\text { guage. }\end{array}$ & .47 & .39 & \\
\hline $\begin{array}{l}\text { 11. Good learners of a second language usually know a lot of grammar } \\
\text { rules. }\end{array}$ & .58 & .34 & \\
\hline $\begin{array}{l}\text { 12. Knowing grammar rules helps communication in a second lan- } \\
\text { guage. }\end{array}$ & .62 & & \\
\hline 14. The study of Grammar helps in learning a second language & .62 & & -.30 \\
\hline $\begin{array}{l}\text { 17. Knowledge about grammar rules helps in understanding other peo- } \\
\text { ple's speech. }\end{array}$ & .42 & & .40 \\
\hline $\begin{array}{l}\text { 19. When I read a sentence in a second language, I try to figure out the } \\
\text { grammar. }\end{array}$ & .41 & & .30 \\
\hline $\begin{array}{l}\text { 22. I feel cheated if a teacher does not correct the written work I hand } \\
\text { in. }\end{array}$ & .39 & -.32 & .34 \\
\hline $\begin{array}{l}\text { 20. Second language writing is not good if it has a lot of grammar mis- } \\
\text { takes. }\end{array}$ & .40 & -.45 & \\
\hline $\begin{array}{l}\text { 21. One way to improve my reading ability is to increase my knowledge } \\
\text { of grammar. }\end{array}$ & .56 & .40 & -.30 \\
\hline \multicolumn{4}{|l|}{ - Priority of Communication } \\
\hline $\begin{array}{l}\text { 6. I can communicate in a second language without knowing the gram- } \\
\text { mar rules. }\end{array}$ & & .41 & -.41 \\
\hline $\begin{array}{l}\text { 24. It is more important to practice a second language in real-life situa- } \\
\text { tions than to practice grammar rules. }\end{array}$ & -.32 & .39 & .34 \\
\hline $\begin{array}{l}\text { - Negative Attitudes To Grammar Instruction \& Error Correction } \\
\text { 4. When I make errors in speaking a second language, I like my teacher } \\
\text { to correct them. }\end{array}$ & & & .43 \\
\hline
\end{tabular}




\begin{tabular}{|c|c|c|c|}
\hline $\begin{array}{l}\text { 7. Teachers should not correct students when they make errors in class. } \\
\text { 10. I like to be corrected by my classmates in small group work. }\end{array}$ & & -.45 & .60 \\
\hline 13. I like it when my teacher explains grammar rules. & -.34 & & .51 \\
\hline $\begin{array}{l}\text { 15. When I have problems during conversation activities, it helps me to } \\
\text { nave my teacher explain grammar rules. }\end{array}$ & & -.34 & .42 \\
\hline $\begin{array}{l}\text { 16. There should be more formal study of grammar in my second lan- } \\
\text { guage class. }\end{array}$ & & & .75 \\
\hline 23. I dislike it when I am corrected in class. & -.35 & & .51 \\
\hline $\begin{array}{l}\text { 18. When I make grammar errors in writing in a second language, I like } \\
\text { my teacher to correct them. }\end{array}$ & & -.52 & .43 \\
\hline
\end{tabular}

As it can be seen in table one, there are some differences between the Loewen et al study factors and those identified in the current study. The factor analysis of the Loewen et al's (2009) study identified six factors but in the current research only three factors were identified. One possible reason for this is the high degree of similarity among the categories. Loewen et al study's identified factors were "efficacy of grammar, negative attitudes to error correction, priority of communication, importance of grammar, importance of grammatical accuracy and negative attitudes to grammar instruction". But the factors identified in this research were: importance of grammar, priority of communication, and negative attitudes to grammar instruction and error correction". As it is clear from Loewen et al's (2009) study the factors identified have some overlaps with each other. That is, it is very difficult for the students to notice the differences between, say, efficacy of grammar and importance of grammar or the negative attitudes to grammar instruction and negative attitudes to error correction due to the fact that grammar instruction is usually accompanied by error correction.

Therefore, according to the Iranian students' perspectives these three components can be considered the most important benefits of grammar instruction and error correction. Therefore, while instructing grammar, teachers should invest more time and energy to take into consideration these factors. Results of the factor analysis showed that one of the main benefits of teaching grammar is helping students to communicate more effectively. That is, according to Iranian students' perspectives, promoting accuracy is one of the main advantages derived from teaching instruction. Also, the Iranian sample students believed that grammar instruction and error correction are two inseparable aspects of language teaching. Therefore, these two components were included in one factor. This idea is quietly tuned with the some researchers' position that error correction is a type of focus on form and thus a type of grammatical focus (Ellis, 2001). 


\section{Qualitative Results}

In addition to the quantitative items, learners were given four open-ended prompts. The themes that were identified for each of the prompts will be presented in turn.

\section{I like studying grammar because...}

In response to this prompt, several themes emerged. Many learners felt that the studying of grammar can help them in using English for communicative purposes. Some learners commented that grammar constitutes the core of language and learning grammar should be considered an integral part of language teaching and learning. Some other learners commented that learning grammar can help them with specific aspects of language. For example, they said: "learning grammar is useful in reading and writing"; grammar helps me in communicating with other people. An interesting comment from one of the students referred to the joy that she felt while studying grammar. From the learners' responses, it seems that almost all the learners have understood the importance of mastering grammar. This can be seen from their comments: "I like grammar due to its relationships with other components of language, that is, solely knows a bundle of words cannot help to derive the exact meaning of the texts. To achieve this, grammar should come to help me".

Based on what went on above, it can be seen that learners' comments range from intrinsic to extrinsic reasons. Some relate the benefits of learning grammar to better understanding a piece of text and some to using language for communicating purposes. To sum up, almost all students emphasized the importance of grammar instruction and its contribution to other aspects of language.

\section{I dislike studying grammar because...}

Regarding the second prompt that investigated the negative attitude of the learners towards grammar instruction, some learners just reported that the disliked the grammar without any further elaboration. Some comments showed the misconceptions of some of the students regarding the role that grammar play in all aspects of language use because some of them said that grammar has no role in language use and as the main purpose of language acquisition is to communicate with native speakers, learning grammar cannot help them in this matter. Few

students used the term 'boring' or its synonyms to describe their dislike to learn grammar and 
they believed that this was due to the teacher-fronted orientation of language classrooms and the initiation-response-feedback (IRF) type of questions usually raised in the grammar instruction classes. According to the students' responses, part of this dislike derives from the nature of grammar itself, that is, it is full of rules, exception to rules and etc. Some students, for example, said that they disliked grammar because they should memorize the rules and the exceptions to them.

\section{I do not like to be taught in the following ways...}

Regarding the preferred way of grammar instruction, the students expressed varied views. Some of them reacted harshly to the out of context teaching of grammar without relating the rules to some sentence-based examples. They felt that this method of grammar instruction cannot help them in the real world context. One student commented in an interesting way: "I do not like the teacher writing the grammatical one the board and making us to repeat that particular grammatical rules. Some other students said that they did not like implicit approach to grammar instruction, that is, the teacher asks the students to infer the rules from some presented examples. Among the idiosyncratic responses, some students said that they did not like working on grammar in groups. Although the current students were usually taught grammar using some traditional drills either specified in their books or preferred by their teachers, some of them answered surprisingly that they like to be taught grammar using games and communicative activities.

\section{I like to be taught in the following way....}

As it is clear from this last question, the students were asked about their attitudes regarding their preferences for the techniques of grammar instruction. Some students commented that they liked the grammar to be presented to them in a formulaic manner, that is, they are taught in an explicit way. Some other students said that the grammatical rule presentation be followed by using those rules in sentences so that they can better understand the usage of those rules. The students also related the grammar instruction to the language skills, that is, they commented that after grammar instruction by the teacher, the students should be asked to use those rules while writing or speaking. Some other students commented in inter- 
esting ways for example they said that the grammar instruction should done via films or animation presentation.

\section{Conclusion}

This study investigated the importance of grammar instruction and error correction from the students' perspectives. This type of analysis is important because many studies have emphasized the determining effect of students' beliefs and attitudes on the success or failure of language teaching program (Altan 2006; Hawkey 2006; Kern 1995; Peacock 2001; Sakui \& Gaies 1999;). In addition to the mere qualitative analysis of this effect, the present study conducted PCA to determine the components underlying the learners' attitudes towards grammar instruction and error correction.

This study showed that Iranian high school students have varied attitudes towards the role of grammar instruction and the way that grammar should be taught. Their ideas regarding the role of grammar ranged from its use in communication to the mere use of grammar in learning English for academic purposes. Also, the activities preferred by the students included a range of both mechanical and meaningful drills.

The implication of this study for L2 teachers and practitioners is that to maintain the students' interest and motivation teachers must vary the type of activities and procedures to teach grammatical points. Teachers should come to this understanding that students' beliefs and attitudes have a determining effect on the success or failure of their teaching enterprise. This study intended to persuade L2 teachers to involve the students in process of teaching language, and especially grammar, to create an authentic teaching environment. Of course, it should be emphasized that students' beliefs may be somehow inapplicable in the context of language teaching due to some limitations such as management problems, lack of time, lack of teacher experience and expertise and etc. But all these problems should not discourage L2 teacher not to consider students' attitudes.

The study suffers from some limitations. First, the mere use of questionnaire cannot give us a complete picture of such descriptive research in which learners' attitudes and beliefs are under investigation. To have a more comprehensive understanding of the students' beliefs, some other elicitation devices such as observation or diary journal seem to complement the 
obtained data. Second, students' familiarity with language questionnaires especially those that make use of Likert Scale seems vital to the outcome of study. To overcome this problem, the researcher had some introduction hours with the subjects so as to minimize any effects of any intervening variables. The last and not the least is the nature of open-ended questions that asked the subjects to express their ideas in whatever way that they felt comfortable. Usually, the subjects with limited language learning experience have some difficulties in expressing their own views based on the open-ended questions. This is due to the fact that formulating one's sentences about what one believes about grammar instruction and error correction requires high degree of consciousness. Therefore, when giving students, especially those of limited proficiency, some open-ended questions of this sort, they should be expected to answer these questions completely and provide the researcher with illuminating questions.

\section{References}

Altan, M. Z. (2006). Beliefs about language learning of foreign language-major university students. Australian Journal of Teacher Education, 31, 45-52.

Bachman, L.F. \& Palmer, A.S. (1996). Language testing in practice. Oxford: Oxford University Press

Batstone, R., \& Ellis, R. (2009). Principled grammar teaching. System, 37, 194-204.

Basturkmen, H., Loewen, S., \& Ellis. R. (2004). Teachers' stated beliefs about incidental focus on form and their classroom practices. Applied Linguistics, 25, 243-272.

Borg, S. (1999). Studying teacher cognition in second language grammar teaching. System, 27, 19-31.

Borg, S. (2003). Teacher cognition in language teaching: A review of research on what language teachers think, know, believe, and do. Language Teaching, 36, 81-109.

Burgess, J., \& Etherington, S. (2002). Focus on grammatical form: explicit or implicit? System $30,433-458$

Celce-Murcia, M. (1985). Making informed decisions about the role of grammar in language teaching. TESOL Newsletter, 1, 4-5.

Celce-Murcia, M. (1991). Grammar pedagogy in second and foreign language teaching. TESOL Quarterly, 25, 452-481.

Cullen, R. (2008). Teaching grammar as a liberating force. ELT Journal, 62, 221-230.

Ellis, R. (1984). Can syntax be taught? A study of the effects of formal instruction on the acquisition of WH questions by children. Applied Linguistics, 5, 138-155. 
Ellis, R. (1995). Interpretation tasks for grammar teaching. TESOL Quarterly, 29, 87-107.

Ellis, R. (2001). Investigating form-focused instruction. Language Learning, 51, 1-46.

Ellis, R. (2006). Current issues in the teaching of grammar: An SLA perspective. TESOL Quarterly, 40, 83-107.

Flavell, J.H. (1979). Metacognition and cognitive monitoring: a new area of cognitive developmental inquiry. American Psychologist, 34, 906-911.

Fotos, S.S. (1994). Integrating grammar instruction and communicative language use through grammar consciousness-raising tasks. TESOL Quarterly, 28, 323-353.

Ganjabi, M. (2011). Effective Foreign Language Teaching: a Matter of Iranian Students' and Teachers’ Beliefs. English Language Teaching, 4, 46-54.

Gass, S.M., \& Selinker, L. (2008). Second language acquisition: an introductory course. New York: Routledge.

Hawkey, R. (2006). Teacher and learner perceptions of language learning activity. ELT, 60, 242-252.

Higgs, T. V., \& Clifford, R. (1982). The push towards communication. In T. V. Higgs (Ed.), Curriculum, competence, and the foreign language teacher (pp. 57-79). Lincolnwood, IL: National Textbook.

Horwitz, E. K. (1988). The beliefs about language learning of beginning university foreign language students. Modern Language Journal, 72, 283- 294.

Horwitz, E. K. (1999). Cultural and situational influences on foreign language learners' beliefs about language learning: a review of BALLI studies. System, 27, 557-576.

Kern, R. (1995). Students and teachers' beliefs about language learning. Foreign Language Annals, 28, 71-92.

Klapper, J. \& Rees, J. (2003). Reviewing the case for explicit grammar instruction in the university foreign language learning context. Language Teaching Research, 7, 285-314.

Krashen, S. (1985). The Input Hypothesis: issues and implications. London: Longman.

Krashen, S. (1999). Seeking a role for grammar: a review of some recent studies. Foreign Language Annals, 32, 245-257.

Lalande, J. F. (1982). Reducing composition errors: An experiment. Modern Language Journal, 66, 140-149.

Larsen-Freeman, D. \& Long, M.H. (1991). An introduction to second language acquisition research. UK: Longman. 
Lightbown, P.M. (1998). The importance of timing in focus on form. In C. Doughty \& J. Williams (Eds.), Focus on form in classroom second language acquisition (pp.177-197). New York: Cambridge University Press.

Lightbown, P., \& Spada, N. (1990). Focus on form and corrective feedback in communicative language teaching: effects on second language learning. Studies in Second Language Acquisition, 6, 186-214.

Loewen, S., Li, S., Fei, F., Thompson, A., Nakatsukasa, K., Ahn, S., \& Chen, X. (2009). Second language learners' beliefs about grammar instruction and error correction. The Modern Language Journal, 93, 91-104.

Long, M. (1983). Does second language instruction make a difference? A review of research. TESOL Quarterly, 17, 359-382.

Long, M.H. (2001). Focus on form: a design feature in language teaching methodology

. In C. N. Candlin \& N. Mercer (Eds.), English language teaching in its social context (pp. 180-190). London: Routledge.

Long, M.H., \& Robinson, P. (1998). Focus on form: theory, research and practice. In C. Doughty \& J. Williams (Eds.), Focus on Form in Classroom Second Language Acquisition (pp. 15-41). Cambridge: Cambridge University Press.

Lyster, R., Lightbown, P. M., \& Spada, N. (1999). A response to Truscott's "What's wrong with oral grammar correction." Canadian Modern Language Review, 55, 457-467.

McCargar, D. (1993). Teacher and student role expectations: cross-cultural differences and implications. Modern Language Journal, 77, 192-207.

Pallant, J. (2007). SPSS: Survival manual. Berkshire: Open University Press.

Peacock, M. (2001). Pre-service ESL teachers' beliefs about second language learning: a longitudinal study. System, 29, 177-195.

Phipps, S., \& Borg, S. (2009). Exploring tensions between teachers' grammar teaching beliefs and practices. System, 37, 380-390.

Rutherford, W. E. \& Sharwood Smith, M. (1988). Grammar and second language teaching. New York: Newbury House.

Sakui, K. \& Gaies, S.J. (1999). Investigating Japanese learners' beliefs about language learning. System 27, 473-492.

Schachter, J. (1991). Corrective feedback in historical perspective. Second Language Research, 7, 89-102. 
Schulz, R. (1996). Focus on form in the foreign language classroom: Students' and teachers' views on error correction and the role of grammar. Foreign Language Annals, 17, 195-202.

Schulz, R.A. (2001). Cultural differences in student and teacher perceptions concerning the role of grammar instruction and corrective feedback: USA-Colombia. The Modern Language Journal, 85, 244-258.

Seidenberg, M.S., \& MacDonald, M.C. (1999). A probabilistic constraints approach to language acquisition and processing. Cognitive Science, 23, 569-588.

Semke, H.D. (1984). Effects of the red pen. Foreign Language Annals, 17, 195-202.

Skehan, P. (2001). Comprehension and production strategies in language learning. In C. N. Candlin \& N. Mercer (Eds.), English language teaching in its social context (pp. 7589). London: Routledge.

Terrell, T. (1977). A natural approach to second language acquisition and learning. Modern Language Journal, 61, 325-337.

Truscott, J. (1999). What's wrong with oral grammar correction?. Canadian Modern Language Review, 55, 437-456.

Valette, R. M. (1991). Proficiency and the prevention of fossilization. Modern Language Journal, 75, 325-328.

Van Lier, L. (2001). Constraints and resources in classroom talk: issues of equality and symmetry. In C. N. Candlin \& N. Mercer (Eds.), English language teaching in its social context. London: Routledge.

Wenden, A. L. (1999). An introduction to Metacognitive Knowledge and Beliefs in Language Learning: beyond the basics. System 27, 435-441

Yang, N.D. (1999). The relationship between EFL learners' beliefs and learning strategy use. System, 27, 515-535.

Widdowson, H. 1990. Aspects of Language Teaching. Oxford: Oxford University Press. 


\section{Appendix A. Grammar Instruction and error correction Questionnaire}

Note: The questions below ask you what you think about studying grammar rules and about your motivation for learning a second language. Read each statement and decide how strongly you agree or disagree, circling the appropriate number. If a question doesn't apply to you, you can circle not applicable.

\section{Quantitative section:}

1. Studying grammar formally is essential for mastering a second language.
A. Strongly Agree
B. Agree
C. Disagree
D. Strongly disagree
D. Not applicable

2. I usually keep grammar rules in mind when I write in a second language.

3. Knowing a lot about grammar helps my reading.

4. When I make errors in speaking a second language, I like my teacher to correct them.

5. My second language improves most quickly if I study the grammar of the language.

6 . I can communicate in a second language without knowing the grammar rules.

7. Teachers should not correct students when they make errors in class.

8. I like studying grammar.

9. People will respect me if I use correct grammar when speaking a second language.

10. I like to be corrected by my classmates in small group work.

11. Good learners of a second language usually know a lot of grammar rules.

12. Knowing grammar rules helps communication in a second language.

13. I like it when my teacher explains grammar rules.

14. The study of grammar helps in learning a second language.

15. It is more important to practice a second language in real-life situations than to practice grammar rules.

16. When I have a problem during conversation activities, it helps me to have my teacher explain grammar rules.

17. There should be more formal study of grammar in my second language class.

18. Knowledge about grammar rules helps in understanding other people's speech.

19. I dislike it when I am corrected in class.

20. When I make grammar errors in writing in a second language, I like my teacher to correct them.

21. When I read a sentence in a second language, I try to figure out the grammar.

22. I feel cheated if a teacher does not correct the written work I hand in.

23. Second language writing is not good if it has a lot of grammar mistakes.

24. One way to improve my reading ability is to increase my knowledge of grammar.

\section{Qualitative section:}

The following questions allow you to respond in your own words. You may write in whatever language you are most comfortable.

I like studying grammar because...

I dislike studying grammar because...

I don't like to be taught grammar in the following ways...

I like to be taught grammar in the following ways... 